\title{
Promoting the integration of Engineering, Ecology and Limnology: the Ecohydrological approach applied to Amazon reservoir construction
}

\author{
Tundisi, JG. ${ }^{a, b *}$, Matsumura-Tundisi, T. $^{a}$ and Tundisi, JEM. ${ }^{a}$ \\ ${ }^{a}$ Instituto Internacional de Ecologia e de Gerenciamento Ambiental - IIE, Rua Bento Carlos, 750, Centro, CEP 13560-660, \\ São Carlos, SP, Brazil \\ 'Universidade Feevale, Rodovia RS 239, 2755, Vila Nova, CEP 93525-075, Novo Hamburgo, RS, Brazil \\ *e-mail: tundisi@iiie.com.br
}

Received: July 21, 2015 - Accepted: July 21, 2015 - Distributed: August 31, 2015

(With 1 figure)

\begin{abstract}
Amazon watersheds are a complex ecosystem: the interaction between terrestrial and aquatic ecosystems and the water level fluctuations are the main forcing function that regulates the biodiversity, the evolutionary processes and the interaction between terrestrial and aquatic biota in the large internal deltas, the extensive floodplains regions and the network of channels, creeks, rivers, meanders and lakes (Haffer, 2008). Chemical and physical environment resulting from the inundation periods and the forest, promotes a chain of morphological, anatomical, physiological, geological and ethological adaptations with its characteristics structures (Junk et al., 1989; Alho, 2008). Food chains show large changes in their connections and organization during and after the flooding period (Junk, 1997).

Reservoirs disrupt the dynamics of these ecosystems and change the organization patterns of floodplains, lakes creeks and rivers (Tundisi et al., 2008c). Large reservoirs affect the forest cover, due to deforestation of the future inundation area; reservoir also changes the fluvial dynamics, upstream and downstream the Power Plant Unit (Agostinho et al., 2009).

In order to preserve the main ecological functions of the Amazonian ecosystems it is necessary to introduce ecohydrological concepts combined with engineering procedures in the construction of the Amazonian reservoirs. This also includes the perspectives of the influence of future climatic changes in the hydrological cycles (Martinelli et al., 2012). Since hydropower from the Amazon watershed is essential to Brazil, a well designed operation system for reservoir construction, should consider:
\end{abstract}

- Low retention time in the operation.

- Less inundated forest area (smaller reservoirs).
- Preserving local and regional biodiversity (Tundisi et al., 2008a,b)

- Preserving the connectivity of tributaries and lakes with the main river. This can be achieved by regulation and control of the operation procedure.

- Reforestation of reservoir boundaries, with native species.

- Protection of wetlands in the watershed.

- Avoiding chains of reservoirs. If natural spaces in rivers are left intact, preservation of natural areas will maintain biodiversity and capacity to recover natural functions of the river.

- Preserving entire rivers in the Amazon watershed in order to maintain large regions free of man made structures promoting the continuity of the evolutionary process (Agostinho et al., 2009; Tundisi et al., 2014).

The integration of structure and function in the planning of future Amazonian reservoirs is essential for the maintenance of the ecological dynamics of the region (Jorgensen, 1992). Engineering procedures, ecohydrological principles and limnological approaches are not incompatible (Zalewski, 2010, 2014).

The Belo Monte Power Plant, Unit is example of a consistent effort to integrate structure and function in a large scale intervention promoting an evolution in the approach to manage reservoirs in a complex ecosystem, such as the Amazon and Xingu River watersheds.

The hydrograph of Xingu River (1969-2015) was the basis for the design of the operation system of the reservoir and the maintenance of the ecological flows downstream as well as the biodiversity (aquatic and terrestrial) with reduced impact (Figure 1). 


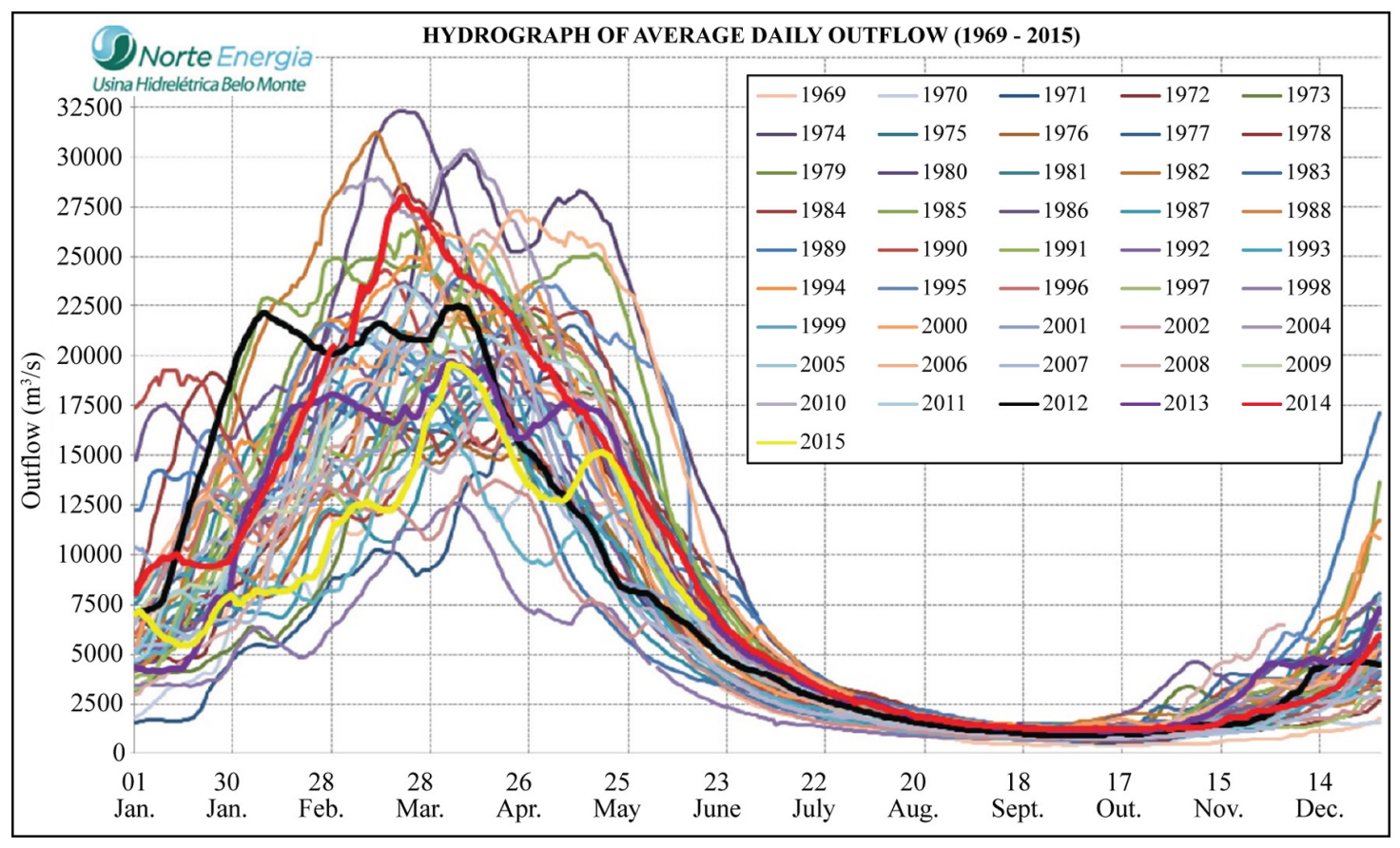

Figure 1. The hidrograph of daily outflow in the Xingu River. This hydrograph was the basis for the design of the operation system and the maintenance of ecological flows downstream the main reservoir.

\section{References}

AGOSTINHO, AA., BONNECKER, CC., RODRIGUES, L., GOMES, LC. and MAGELA, TS., 2009. Biodiversity and conservation. Brazilian Journal of Biology, vol. 69, no. 2, supplement, p. 459-755.

ALHO, CJR., 2008. Biodiversity of the Pantanal: response to seasonal flooding regime and to environmental degradation. Brazilian Journal of Biology, vol. 68, no. 4, supplement, p. 957-966. http://dx.doi.org/10.1590/S1519-69842008000500005. PMid:19197468.

HAFFER J., 2008. Hypothesis to explain the origin of species in Amazonia. Brazilian Journal of Biology, vol. 68, no. 4, supplement, p. 917-947.

JORGENSEN, SE., 1992. Integration of ecosystem theories: a pattern. Heidelberg: Elsevier. 383 p.

JUNK, WJ., 1997. The central amazon floodplain: ecology of a pulsing system. Berlim: Springer Valaz. 526 p. Ecological studies, vol. 126.

JUNK, WJ., BAYLEY, PB. and SPARKS, RE., 1989. The flood pulse concept in river floodplain systems. In DODGE, DP. (Ed.). Proceedings of the International Large River Symposium (LARS), 1989. Ottawa. Ontario: Fisheries and Oceans. p. 110-127. Canadian Special Publication of Fisheries and Aquatic Sciences, vol. 106.

MARTINELLI, LA., OMETTO, JPHB. and PINTO, AS., 2012. Climate change and biogeochemistry Brazilian biomes. Brazilian Journal of Biology, vol. 72, no. 3, supplement, p. 633-785.
TUNDISI, JG., MATSUMURA-TUNDISI, T. and ABE, DS., 2008a. The ecological dynamics of Barra Bonita (Tietê River, SP, Brazil) reservoir: implications for its biodiversity. Brazilian Journal of Biology, vol. 68, no. 4, supplement, p. 1079-1098. http:// dx.doi.org/10.1590/S1519-69842008000500015. PMid:19197478.

TUNDISI, JG. and MATSUMURA-TUNDISI, T., $2008 \mathrm{~b}$. Biodiversity in the neotropics: ecological, economical and social values. Brazilian Journal of Biology, vol. 68, no. 4, supplement, p. 913-915. http://dx.doi.org/10.1590/S1519-69842008000500002. PMid:19197465.

TUNDISI, JG., MATSUMURA-TUNDISI, T. and TUNDISI, JEM., 2008c. Reservoir and human well being: new challenges for evaluating impacts and benefits in the neotropics. Brazilian Journal of Biology, vol. 68, no. 4, supplement, p. 1133-1135. http:// dx.doi.org/10.1590/S1519-69842008000500020. PMid:19197483.

TUNDISI, JG., GOLDEMBERG, J., MATSUMURA-TUNDISI, T. and SARAIVA, ACF., 2014. How many more dams in the Amazon? Energy Policy, vol. 74, p. 703-708. http://dx.doi. org/10.1016/j.enpol.2014.07.013.

ZALEWSKI, M., 2010. Ecohydrology for the compensation of Global change. Brazilian Journal of Biology, vol. 70, no. 3, supplement, p. 689-695. http://dx.doi.org/10.1590/S151969842010000400001 . PMid:21085775.

ZALEWSKI, M., 2014. Ecohydrology, biotechnology and engineering for cost efficiency in reaching the sustainability of the biosphere. Ecohydrology and Hydrobiology, vol. 14, no. 1, p. 14-20. http://dx.doi.org/10.1016/j.ecohyd.2014.01.006. 